To Cite: Lee, F. L. F., \& Lin, A. M. Y. (2006). Newspaper editorial discourse and the politics of self-censorship in Hong Kong. Discourse and Society, 17(3), 331-358.

\title{
Newspaper Editorial Discourse and the Politics of Self-censorship in Hong Kong
}

(Short title: Newspaper Editorial Discourse and Self-censorship)

(Word Count: about 12,500 words, including abstract, notes and references)

(To appear in Discourse \& Society in September, 2006)

Francis L. F. Lee

And

Angel M. Y. Lin 


\title{
Newspaper Editorial Discourse and the Politics of Self-censorship in Hong Kong
}

\begin{abstract}
In transitional societies where political pressure on the press coupled with a commercial media system and a professional journalistic culture, the politics of selfcensorship is likely to involve a strategic contest between the media and political actors. Language plays a significant role in this contest. The present study focuses on the case of Hong Kong. It analyzes how two local newspapers, facing an important yet sensitive political issue, constructed two different overall storylines and used two different sets of discursive strategies in their editorials to handle political pressure, market credibility, and journalistic integrity simultaneously. The elite-oriented Ming Pao constructed a storyline of the debate being a factional struggle in order to posit itself as an impartial arbitrator. The approach was further sustained and justified by the discursive strategies of balanced and qualified criticisms and the rhetoric of rational discussion. The mass-oriented Apple Daily, on the other hand, constructed a storyline of a sovereign people whose rights are encroached upon by a powerful entity. The paper was therefore much more critical towards the power center. Nevertheless, it also appropriated the dominant discourse, constructed internal contradictions, and decentralized the Chinese Central government to smooth out the radicalism of its criticisms.
\end{abstract}

\section{Keywords}

Language and politics, media self-censorship, newspaper editorial discourse, positioning theory, journalistic objectivity, Hong Kong 


\section{Newspaper Editorial Discourse and the Politics of Self-censorship in Hong Kong}

\section{Introduction}

Self-censorship is a major threat to press freedom around the world. Even in democratic countries where direct government suppression of the press is absent, news organizations may still censor their own coverage on sensitive topics for political and economic reasons (Bagdikian, 2004; McChesney, 2004). In authoritarian countries, selfcensorship is often institutionalized in newsrooms and internalized by journalists (Mickiewicz, 2000; Sukosd, 2000). The most intriguing cases, however, occur in transitional societies where severe political pressure on the press is combined with a commercial/commercializing media system and a professional/professionalizing journalistic force. In these societies, on the one hand, the possibility of direct political repercussions could lead news organizations to think twice on whether to publish certain stories or how to cover particular topics (e.g., Zhao, 1998; Amin, 2002). But on the other hand, the commercial orientations of the news organizations and the professionalism of the journalists may occasionally require them to defy the attempts of government control. It results in a tension-filled situation and a politics of selfcensorship that involves a strategic contest between media and political actors.

The use of language is likely to be a key part of this strategic contest. Discursive strategies can be devised and deployed by news organizations to make controversial topics, sensitive information, and critical viewpoints 'reportable.' For example, Li (2004) examines the narrative and argumentative strategies a market-oriented newspaper in China used to report on the plight of underprivileged groups in China's urban area. The strategies are, according to Li, instrumental in generating a 'politically correct' coverage that would resonate with urban residents. 
At the same time, media organizations may employ discursive strategies to justify or camouflage their practices of self-censorship, so that they will not be perceived by the public as bowing to political power. Just as cowardice may be disguised as prudence, submissiveness to political power may also hide behind certain journalistic norms. This latter argument is consistent with critical journalism studies' emphasis on the ideological consequences of professionalism (Tuchman, 1978; Fishman, 1980; Hackett and Zhao, 1998).

Based on these considerations, the present study examines the role of discursive strategies in the politics of self-censorship in Hong Kong, where press freedom has been an important concern over the past two decades. It analyzes the editorials of two local newspapers published in the first half of year 2004 on political reform in the city. The analysis addresses the following questions: What are the discursive strategies employed by the newspapers in addressing the issue? Do these strategies aid the expression of critical views? Or do they construct an appearance of professionalism only to mask the docility of the newspaper? Answering these questions should help us better understand the politics of selfcensorship in Hong Kong. More generally, it should contribute to our understanding of the role language plays in the struggle for press freedom in transitional societies.

\section{Press freedom and self-censorship in Hong Kong}

To put the present study into context, a brief discussion of press freedom in Hong Kong is needed. Since the return of Hong Kong to China was confirmed in the early 1980s, the future of press freedom has become a major concern in the city. Early studies showed that power transfer was accompanied by shifts in 'journalistic paradigms' (Chan and Lee, 1991). Most notably, the 'rightist papers,' which were critical towards the Chinese government, have moved towards a more centrist stance over the years. The range of ideological viewpoints propounded by the media has been narrowed down even before the actual handover in 1997. 
However, it does not mean that press freedom was immediately and severely damaged after the handover. Understanding that the 'systems' in the Mainland cannot be imposed upon Hong Kong, the Chinese government has promised that the city will be governed under the principle of 'one country, two systems.' At the same time, China wanted to use Hong Kong as an example to lure Taiwan into re-unification. Hence, in the first few years after the handover, China has refrained from openly intervening into Hong Kong affairs. ${ }^{1}$ Regarding the press, Chinese officials have insisted that the Hong Kong media cannot advocate Taiwan or Tibet independence. They also warned the media not to attack Chinese national leaders personally (Lee and Chu, 1998). But other than these 'national issues,' the media were left largely free to criticize the Hong Kong government on local matters (Lau and To, 2002; Holbig, 2003).

China's reluctance to change Hong Kong's 'existing systems' also means that official media censorship has not been institutionalized. Instead, by the early 1990s, it has already become clear to observers that self-censorship, rather than formal censorship, would constitute the major threat to press freedom in Hong Kong (Scuitto, 1996; Schell, 1996).

Conceptually, self-censorship refers to 'a set of editorial actions ranging from omission, dilution, distortion, change of emphasis, to choice of rhetorical devices by journalists, their organizations, and even the entire media community in anticipation of currying reward and avoiding punishment from the power structure' (Lee, 1998). Its presence in Hong Kong has been documented in different ways. Surveys have shown professional journalists' recognition of the existence of self-censorship in the Hong Kong media (Lee, 1998). Lam (2003), based on his own experience as a journalist, provides a collection of cases of media downplaying negative news and promoting positive news about China. Cheung (2003), through comparing Hong Kong newspapers with the New York Times and a Taiwan daily, illustrates that the Hong Kong media avoided a number of sensitive issues when covering the political tension between the Mainland and Taiwan. 
Nevertheless, the politics of self-censorship is complicated by the commercial nature of the city's media system ${ }^{2}$ and the professionalism of the practitioners. As business organizations, Hong Kong media have to concern themselves not only with political pressure but also with their credibility in the eyes of the consumers. The Hong Kong public largely believes in the media's role in providing an independent forum for public debate and in monitoring the power holders (Chan and So, 2004; Lee et al., 2005). Meeting these public expectations will help media organizations to prosper. This is especially important for newspapers because of the highly competitive local market. ${ }^{3}$ Moreover, providing information to the public, monitoring the government, and to be independent from political and economic power are also the core values of Hong Kong journalists (Chan et al., 1996). From the perspective of professionalism, self-censorship has to be condemned.

As a result, some media organizations have adopted methods that allow them to handle political pressure, market expectations, and journalistic integrity at the same time. ${ }^{4}$ Borrowing the term from Tuchman (1978), Lee (2000) describes such methods as 'strategic rituals.' He identified three such rituals used by the Hong Kong press since the handover. First, newspaper editorials have become more docile, yet many papers continued to provide space for columnists who are highly critical towards the power center. This, in effect, shifts at least part of the political risks from the news organizations to the individual writers. Second, newspapers have used the method of juxtaposition more frequently, so that critical views were balanced by pro-government views. Third, newspapers have also adopted more factual narrative forms in their political news reporting practices.

Analytically, these strategic rituals differ from mere self-censorship in that they are justified by journalistic norms such as objectivity and neutrality. On the positive side, media organizations can alleviate the political pressure they face while continuing to perform their normative and democratic roles by deploying such strategies skillfully. For example, 
juxtaposition at least means a space for critical viewpoints, while sensitive information can be embedded in a factual narrative. But it is also possible that some media organizations are simply deploying such strategies as a mask for their own submissiveness and docility. To remain objective, for example, can be an excuse for not entering into a direct confrontation with the government even when the situation calls for it. As Lee et al. (2004) explicate, professional norms such as objectivity are both constraining and enabling for Hong Kong journalists. Their desirability has to be discerned in each specific case.

\section{Background of the case, data and method}

On January 7, 2004, then Chief Executive of the Hong Kong government Tung Cheehwa delivered his annual Policy Address. Media and public attention was focusing on the issue of democratic reform. The Basic Law, the mini-constitution for the city, recognized the goal of gradual democratization. It specified the method for selecting Hong Kong's Chief Executive only up to year 2002. It was time for the city to review its political system. The democrats were calling for popular elections of the Chief Executive in year 2007, while opinion polls at the time showed a large majority of citizens supporting the idea. ${ }^{5}$

Disappointingly, Tung failed to provide a concrete timetable for democratization. Instead, he revealed the Chinese government's concern with the city's political reform and emphasized the need to discuss with Beijing about certain 'matters of principles' before the review can formally begin. It was soon clear that the Chinese government was determined to assume a leading role in the debate on political reform. It argued that political development in the city is not just a local issue. The line between national and local matters was breached. For the first time since the handover, the Chinese government intervened deeply and openly into public debates in the city. At the same time, the role of the Hong Kong government was severely diminished. 
Despite public demands, the Chinese government was reluctant to allow Hong Kong to further democratize. After months of debates, on April 26, the National People's Congress (NPC) dismissed the possibility of institutionalizing direct elections of Hong Kong's Chief Executive in 2007. It led to widespread public discontent in the city. On July 1, 2004, 200,000 citizens joined a mass demonstration protesting against the Hong Kong and Chinese governments and calling for 'returning the power to the people.' However, government leaders were not to be persuaded. ${ }^{6}$

The debate on democratic reform is a critical case for examining the status of press freedom in Hong Kong. It involves conflicts between national and local interests, which present a dilemma to the Hong Kong media. They risk losing their audience's trust if they betray the local interests of democratization. Yet protecting local interests would mean pitting oneself against the Chinese government. Studying how news organizations dealt with such conflicts in this case would allow us to discern the limits of press freedom in the city.

The present study, however, is more specific in its analytical focus. It examines the discursive strategies used by two newspapers - Ming Pao and Apple Daily - in their editorials. The two papers were selected due to their significance in the media scene in Hong Kong. The mass-oriented Apple Daily is the second most popular newspaper in the city, while Ming Pao has the largest circulation among the elite-oriented papers. More important, large proportions of the readers of the two papers are strong supporters of democratization. It is shown by an on-site survey conducted during the above-mentioned July 1 demonstration: $20 \%$ of the demonstrators were readers of Ming Pao, and 50\% were readers of Apple Daily. ${ }^{7}$

Nevertheless, it does not mean that the two papers have adopted the same approach in covering politics. In the past few years, Ming Pao has been more concerned with maintaining its own credibility through emphasizing the principle of objective news reporting (Lee et al., 2004). Apple Daily, on the other hand, has used criticisms towards the Hong Kong 
government as a marketing strategy (Lee, 2000). In fact, this difference would be very important for understanding the findings in the following analysis.

The present study's focus on editorial is premised upon its special role for newspapers. Editorials are supposed to be persuasive and are less tied by the norm of objectivity. They represent the news organizations' active participation in public debate (Le, 2003). Therefore, they are places where ideological biases can be more readily discerned (Hackett and Zhao, 1994). In the case of Hong Kong, editorials should also be one of the best sites for observing how newspapers handle sensitive political topics.

The textual corpus for the present study consists of 51 editorials of Ming Pao and 68 editorials of Apple Daily. The texts were derived from the online archives of the two papers. They constitute all editorials addressing the various issues related to democratic reform in Hong Kong published by the two papers between January 1 and July $5,2004 .^{8}$

The researchers read through all the texts closely to identify the major discursive strategies adopted in the editorials. Here, a discursive strategy is defined in a general manner: as the use of language and linguistic devices in a way which can be interpreted as a method to handle the political situation at the time. When a discursive strategy was identified, attention was paid to how it was constituted by and practiced with the use of various discursive features, such as lexical choices, metaphors, labeling and categorizations of agents, and argumentative structures. The social significance of the discursive strategies is interpreted in relation to the cultural assumptions and meanings invoked by the language used and also in relation to the larger context of media and politics in Hong Kong. Overall speaking, the analytical approach of this study is inductive and interpretive. It is aimed at constructing what philosophers and anthropologists would call a 'thick description' (Ryle, 1955; Geertz, 2000) of the newspaper editorials under examination, that is, a description of the editorials that would arrive at their social import and significance within their own specific contexts. ${ }^{9}$ 
But as the researchers read through the texts, it was clear that a systematic comparison between the discursive strategies of the two papers can proceed by focusing on the different storylines and subject positions projected by the discourse of the editorials of the two papers as well as how they position different parties and themselves in the storylines. Therefore, we drew on positioning theory in discourse studies for our analysis (Davies and Harre, 1990; Harre and Langenhove, 1999). Positioning is the discursive process whereby selves are located in conversations (and we shall add media discourse) as observably and subjectively coherent participants in jointly produced and accepted 'storylines'. By giving people parts to play in a story (or by providing a cast of different persons in the specific storylines offered), whether it be explicit or implicit, a speaker or writer makes available different subject positions for different parties involved in the storyline. In addition, different storylines are linked to different moral orders, with different sets of norms about what counts as right, legitimate and appropriate to do (Davies and Harre, 1990). While many discourse studies have drawn on positioning theory to analyze conversations or talk-in-interaction, we find the discourse analytic tools of positioning theory useful in our analysis. In fact, the overall storylines constructed by the two newspapers can be regarded as the 'master frameworks' behind the editorials, while the more specific discursive strategies are used to sustain, justify, and/or modify these master frameworks. The following discussion, therefore, begins by analyzing how two political stances and overall storylines were constructed by the two different newspapers. We then proceed to analyze the more specific discursive strategies employed by each newspaper to sustain, justify, and/or modify the storylines.

\section{Constructing political stances and master stories}

In the past, Hong Kong newspapers used to be classified in terms of their political stance towards China. For instance, one well-established social practice among Hong Kong 
people involves calling a paper 'tsan-jung' ${ }^{10}$ (pro-China) or 'jo-paai' (leftist) in contrast to calling a paper 'yauh-paai' (rightist). As mentioned above, many Hong Kong newspapers have moved from these two stances towards a centrist stance even before the 1997 handover (Chan and Lee, 1991). How to encode and decode a political stance depends a lot on the interpretive and sense-making resources shared by members of the discourse community who draw on similar repertoires of linguistic resources to both signal and recognize such categories (Sacks, 1966/1992). We thus start with an analysis of the editorials of the two papers and specifically contrast their lexical choices to see how lexical resources are mobilized to construct different kinds of political stance. Given what happened throughout the debate on democratic reform in Hong Kong, there are certain keywords used by members of the discourse community (or the general public in Hong Kong) - words central to specific critical arguments and serve as key symbols indexing a whole set of presuppositions associated with a category (e.g., 'leftist' or 'pro-China' stance, 'rightist' or 'anti-China' stance, and 'centrist' or neutral/impartial stance). A key set of lexical choices will strongly index a critical stance towards China. For instance, the Chinese government's participation in a debate about affairs in Hong Kong could be phrased as 'gaai-yahp' (intervening) and 'gon-yuh' (interfering). Both Chinese verbs take 'Hong Kong affairs' as its object phrase and index (Silverstein, 2003) a very negative image of the agent, i.e., the subject of the verb. Typically such verbs are used when the agent of the action is a foreign power who meddles in the affairs of another sovereign country; i.e., these verbs are used only when the agent does not have sovereignty over the recipient of the action. As the Chinese government holds legal sovereignty over Hong Kong, when such verbs are used a strong set of assumptions about the independent sovereignty of Hong Kong (albeit not legally ratified) is signaled and asserted.

As Table 1 below shows, interfere or intervene appeared only once in Ming Pao's editorials as a verb to describe Beijing's action, in comparison to Apple Daily's five. 
Moreover, for Apple Daily, China not only intervened, it was described as doing so in a 'chou-bouh' (violent) and 'mouh-leih' (unreasonable) manner. The two adverbs appeared 21 times in the Apple Daily corpus as modifiers of the action verbs of the Chinese government. On the contrary, these two words were never used to modify the action verbs of the Chinese government in Ming Pao's 51 editorials.

[Table 1 about here]

Similarly, the Chinese government's decision to rule out direct elections of the Chief Executive of Hong Kong in year 2007 can be described as a move that disregarded public opinion in the city. The verb 'moh-sih' (disregard) appeared five times in Apple Daily's editorials to characterize the actions or policies of the Chinese government, but it was never used for this purpose by Ming Pao.

Another illustrative example is the use of the term 'mou-ji' (hat). On February 11, China's official Xinhua News Agency published a statement about political development in Hong Kong. The statement emphasized the importance of the city to be governed by 'patriots'. It raised a debate on the proper definition of 'patriotism' in the city. Conservatives in Hong Kong and some mid-level Chinese officials began criticizing democrats in Hong Kong as 'unpatriotic'. Some even accused certain individual democrats as 'maaih-gwok-chaaht' (literally: 'sell-country thieves') or 'hon-gaan' (defectors of the Han race). These terms were used, for instance, in the past to refer to Chinese people who colluded with the Japanese invaders in China during the Second World War and in other wars in ancient Chinese history. These category names invoke strong nationalistic condemnation of a group of inside-people who are not only unpatriotic but also sell out the country's interest to foreign invaders.

In local parlance, 'kau mou-ji' (to cast hats) refers to the act of wrongfully accusing other people by assigning a political category label to them. Therefore, as long as calling someone a traitor or 'sell-country thief' is perceived as not based on valid grounds, it could be 
regarded as a case of a person 'casting hats' on others. Again, as shown in Table 1, Apple Daily used this verbal phrase ('cast hats on') more frequently to accuse the pro-China public figures of unjustifiably calling other people names (such as traitor or 'sell-country thief').

To provide a more holistic textual context for analysis, let us contrast the following excerpts from the two papers and see how they constructed the 'debate on patriotism' differently. The editorials were published amidst heated public debates in the Hong Kong society about whether some Hong Kong people are patriotic (to China) or not and when the organizers of the massive demonstration on 1 July 2003 in Hong Kong had been accused of being unpatriotic by a pro-China public figure:

\section{Excerpt 1:}

... But this kind of accusation is totally devoid of reasons and grounds. It simply exposes Mr. Tsang's intention to stir up conflicts and suppress dissent. Fortunately Mr. Tsang is not the king of the SAR. Otherwise, participants in the July 1 demonstration or June 4 commemoration would have their thoughts examined by Mr. Tsang, who will determine whether people are patriotic or not. (Apple Daily, February 14) Tsang is a Hong Kong-based member of China's National People's Congress. The above passage not only directly criticized Tsang; it also extended the target of Tsang's criticism to include the participants of the July 1 demonstration. This extension makes Tsang's criticism more problematic and condemnable because ordinary citizens who peacefully exercise their rights to express their views are now all on the receiving end of criticism and classified as 'unpatriotic' by a politician who is described as wielding the 'kingly' power to distinguish patriots from non-patriots. These politicians' act of 'casting hats' ('kau mou-zi') on others (i.e., labeling one as patriotic or unpatriotic) is constructed as a threat to common people, invoking the idea of a regression of Hong Kong into an autocratic monarchy, with the people at the mercy of the arbitrary power of a king. 
On the contrary, Ming Pao seemed to be more cautious in singling out anyone to blame. Instead, it characterized the debate as involving two sides that are equally blameworthy. The following passage is illustrative:

\section{Excerpt 2:}

If the discussion surrounding patriotism is calm and rational......then it is a good thing. But the recent debate on patriotism is not like that. It is just different political factions accusing each other and criticizing each other's historical record. The leftists make a fuss out of the democrats' support for the June 4 student movement......; the democrats, in return, questioned the leftists' blind support for the Anti-Rightist Movement and Cultural Revolution. As a result, more and more remote things get talked about; even the civil war between the Communists and the KMT and Sun Yat Sen's ending the rule of the Ching Dynasty were mentioned...... This kind of abstract and subjective debate would only dampen instead of enhance Hong Kong people's patriotism. (February 19, Ming Pao, italics added)

The above excerpt implicitly invokes a storyline with three different groups of people: (1) the 'leftists', (2) the 'democrats' and (3) 'Hong Kong people'. The leftists and the democrats are anaphorically referred to as 'different political factions', implying that they are not impartial but are interested, biased parties each with its own agenda. These two factions are engaged in debates which are 'abstract and subjective'. These debates will not 'enhance' but will 'dampen' the interest of the third (implicitly much larger) group: 'Hong Kong people'. In this storyline, three collective subject positions are offered. The first two subject positions are highly negative ones and the third, 'Hong Kong people', is offered as the subject position for the readers of the newspaper to take up. At the same time, the authorial point of view occupies an almost transcendental, objective, uninterested, and rational subject position. The author, hence, is cast as someone who has the power and legitimacy to evaluate the actions of 
the 'political factions'. It invokes a seemingly rational moral order. The authorial voice invites the readers to take up this 'objective' position. The readers are implicitly led to take a critical stance towards the 'factions' and to see them as biased, interested, and engaged in actions that are damaging to the interest of the larger society.

Interestingly, China is missing in the cast of actors in the storyline, and therefore cannot be on the receiving end of any criticism. This can be regarded as a way to mask the potential culprit by sometimes erasing it, so that it is out of the attention of the readers.

The overall storyline offered by Mingpao as explicated above is very different from the one projected by Apple Daily. In the latter, China is cast conspicuously as the chief 'bad' character, who illegitimately ('violently', 'unreasonably') intervenes in the affairs of Hong Kong people (with the implicit assumption that Hong Kong people have their own sovereignty which is now being threatened by an outside invader). The leftists or pro-China politicians are cast as equally bad characters who are collaborators with China. Hong Kong people are cast as victims and the democrats are cast as leaders and organizers of the victims to put up a resistance (or at least a protest, such as the massive July 1 st demonstration in 2003). In other words, the moral order that Apple Daily's storyline invokes is associated with the rights of a sovereign people (the 'Hong Kong people') to resist an outside power which is violently interfering with the internal affairs of these sovereign people.

We can see that the two newspapers' storylines offer very different subject positions to different parties as well as to the readers. This leads directly to difference in the degree of criticalness of the two papers' editorials. While Apple Daily is full of explicit and strong accusations and criticisms of China and the pro-China politicians, the language style used in Ming Pao is that of the rational, unemotional, seemingly neutral genre. There is a tendency for Ming Pao to avoid criticizing China, often by erasing China from the cast of actors in the storyline offered. However, does this lack of critical language style automatically give us the 
impression that Ming Pao was practicing self-censorship? Or, how could Ming Pao make a case of its own credibility and integrity in light of its apparent docility (albeit explicitly projected as a rational voice)? To address these questions, Ming Pao's lack of a critical language style has to be understood in relation to the other discursive strategies and legitimizing rhetoric that it has employed in their editorials.

\section{The rhetoric of objectivity and rationality}

As discussed earlier, some news organizations in Hong Kong have adopted measures to handle political pressure. One important strategy is what Lee et al. (2004) called 'intensified objectivity.' By claiming to be objective, media organizations absolve themselves from the responsibility of providing critical views. Instead, they can restrict their job to transmitting and balancing the views expressed by social and political actors. This alleviates the political pressure the media have to face without hugely sacrificing the diversity of voices in the public arena. The discourse of the editorials of Ming Pao examined here can be understood in light of this strategy of intensified objectivity. The need to avoid emotional and value-laden language at least partially explains the relative lack of certain words signifying criticisms towards the Chinese government or pro-China politicians. The principle of impartiality can also explain the failure for Ming Pao to single out the conservatives as the main culprits for 'casting hats' on others. More generally, as Excerpt 2 cited in the previous section illustrates, intensified objectivity often manifested itself through balanced criticism (i.e., it has to deliver criticism equally to both or all parties). When an editorial of Ming Pao criticized the leftist politicians, or in the relatively few cases when Chinese officials were criticized, the paper often also criticized the democrats or even the larger group of Hong Kong people. For instance, Ming Pao's editorial on April 28 criticized the democrats for misjudging the power of public opinion, while it also criticized China for suppressing Hong Kong 
people's demand for democracy. In another case, the editorial on January 17 questioned Hong Kong people's understanding of the principle of 'one country' before criticizing the Central government as 'not sensitive enough towards the distinction between the 'two systems'.

However, it is not always possible to locate the mistakes on 'the other side' of the debate in order to balance a criticism towards the leftists or Chinese government. In these situations, another method available to Ming Pao's editorial writers is to qualify criticisms with an equal acknowledgement of the concerns or goodwill of the criticized parties:

\section{Excerpt 3:}

The worries of Beijing officials are not difficult to understand, but criticizing the democrats as unpatriotic cannot help resolving the problem. It only makes the matter worse. (February 19, Ming Pao, emphasis added)

\section{Excerpt 4:}

We do not question the goodwill of the Central [Government], but [it] has not accurately understood public opinion [in Hong Kong]. (April 27, Ming Pao, emphasis added)

Besides this type of explicit acknowledgements, implicit acknowledgements can also be suggested with the use of metaphors:

\section{Excerpt 5:}

We believe that, although the National People's Congress Standing Committee absolutely has the right to interpret the [Basic Law], interpretation of the Basic Law is the last resort; it is a heavy dose of medicine, the medicinal power is too strong and will lead to side effects; it should be used only when necessary. (Ming Pao, April 7) By using medicine as a metaphor, China is cast as the well-intentioned doctor curing the ills of Hong Kong society. The passage not only asserted the goodwill of the National People's Congress, but also implicitly suggested that there is an illness that needs to be cured. 
The passage did criticize the current action being taken as inappropriate. Yet at the same time, it legitimized China's actions, though not liked by the 'patient' of Hong Kong people, as necessary and originating from the good intentions of someone like a doctor. In the end, China's action was at least regarded as 'medicine,' not poison. By casting China as a wellintentioned doctor treating the collective patient of Hong Kong people, a moral order was invoked which justified or legitmized China's actions towards Hong Kong. It also undermined the rights of Hong Kong people to say 'no' to these actions, as how can a patient object to the medicine of the doctor?

Another important aspect of editorials, as well as news contents in general, is the use of information sources (Tuchman, 1978; Fishman, 1980; Le, 2004). In their study of investigative journalism, Ettema and Glasser (1998) show how journalists 'objectify' their value judgments and moral claims by 'hard facts,' such as written codes of ethics, laws, and statistics. A similar type of 'hard facts' available for Hong Kong newspapers is opinion poll findings. In fact, 17 of the 51 Ming Pao editorials involved the citation of poll findings of some kind, so that 'objective' grounds were seemingly provided for the opinions given in the editorials. In contrast, only two of Apple Daily's 68 editorials have cited poll findings. It does not mean that Apple Daily gave public opinion a less important role in the debate on democratic reform. On the contrary, it is arguable that Apple Daily has recognized the public as active agents to a larger extent. In various editorials, Apple Daily actually suggested the citizen readers to participate in voting or protests to express their quests for democratic reform. Ming Pao's editorial, on the other hand, tended to treat 'public opinion' merely as 'facts' that political leaders have to respond to, thus objectifying concrete agents and their actions (Hong Kong citizens voicing their views) as abstract, scientific findings of opinion polls. An illustrative example is the editorial on April 12. While commenting on how the police had handled a pro-democracy demonstration that occurred on April 11, the editorial 
stated that: 'In fact, the flow of people in a demonstration is similar to public opinion. It is better to divert it than to contain it. Otherwise, [the government] will only create a crisis for itself' (italics added). Through the paradigmatic word choices of 'flow,' 'divert,' and 'contain,' the passage treated the handling the flow of people in a demonstration and public opinion as the handling of flood. In the analogy, 'public opinion' becomes an administrative problematic rather than a democratic principle with moral force. A totally different imagery that of the rational scientist finding the most efficient way to handle and contain flows and floods - with a totally different moral order is thus projected and asserted. Hong Kong people are cast as 'objects' which are likened to natural disasters to manage, contain and control and not active citizens with their agency and rights which demand and deserve respect.

[Table 2 about here]

In fact, the different roles assigned to 'the public' and 'public opinion' by the two newspapers constituted key aspects of the overall storyline provided by the two papers. How the two papers characterized agents in the debate thus deserve some further elaboration here. As Table 2 shows, both newspapers mainly used the labels 'Central Government,' 'Beijing Government,' or simply 'Beijing' to characterize the Chinese government. What is peculiar to Apple Daily, however, is its occasional use of the phrase 'dong-kyuhn-je' (power-wielders) to refer to Chinese leaders. This phrase emphasizes the actual political power that Chinese leaders possess and conveys a weaker sense of legitimacy when compared with labels such as 'Central Government.' But the most important and dramatic difference between the two papers is the extent to which the Democratic Party was named and the phrase 'mahn-jyu-paai' (the democrats' faction) was used. The Democratic Party is the largest pro-democracy political party in Hong Kong, while 'the democrats' faction' is used in public discourse as a label to encompass all local politicians supportive towards quicker democratization of the city. Apple Daily almost did not mention the two terms at all. This can be seen as a significant 
absence, which implies that such a term is a derogatory category name used by outsiders (Sacks, 1966/1972).

A closer examination of Apple Daily's editorials shows that individual politicians who could be categorized as belonging to the 'democrats' factions' (e.g., by Ming Pao) are often called 'popularly elected legislators' or simply 'representatives of public opinions.' These are insiders' category names (such as the name 'hotrodders' employed by car-racing youths to call themselves, see Sacks, 1966/1992). By using such positive category names, Apple Daily foregrounded the public support that was arguably backing the democrats. At the same time, these labels also suggest that the actual conflict involved in the debate of democratic reform was one between the Chinese government and the Hong Kong public, with the 'democrats' serving merely as the public's representatives.

In contrast, the term 'the democrats' faction' appeared very frequently in Ming Pao's editorials. More important, the link between 'the democrats' faction' and 'public opinion' is much more tenuous and questionable in Ming Pao's editorials, as in the following example:

\section{Excerpt 6:}

If Beijing is willing to make peace with the democrats......the democrats will face huge public pressure to become a more responsible political party, instead of going against the government all the time. (Ming Pao, February 19)

This passage can be understood only with a number of assumptions which contribute to the "local coherence" (van Dijk, 1988) of the text. These assumptions include at least the following: 1) the democrats have been going against the government all the time, and 2) the public regards this as irresponsible. These assumptions, of course, were not created out of nothing, but were indeed negative views towards the democrats widely circulated in public discourse. In other words, Ming Pao drew upon such negative views and discourses about the Democratic Party in Hong Kong to dissociate it from the interests of the larger public. For 
Ming Pao, the conflict in the debate on democratic reform was mainly between the democrats and the Chinese government. The public is a third party whose interests are not necessarily represented by either side.

Certainly, positioning of the democrats adopted by Apple Daily and Ming Pao are not inconsequential. Setting the conflict as one between citizens and power holders and positioning the democrats as 'representatives of public opinion' makes it imperative for Apple Daily to stand by public opinion, argue strongly for democracy, support the democrats, and criticize the Chinese government. On the contrary, phrasing the opposition between the Chinese government and the democrats as the opposition put up by a particular faction of politicians who may or may not be serving the public interests makes it more legitimate for Ming Pao to adhere to the principle of impartiality.

Last but not least, Ming Pao adopted the principle of proceduralism in their editorials' treatment of democratic reform in Hong Kong. Proceduralism is the idea that an outcome can be regarded as just and legitimate as long as it results from people following a set of fair and impartial procedures (see Rawls, 1973: 83-90). Hence, one way for Ming Pao to highlight its 'transcendental' status as an impartial observer and arbitrator of the debate on democratic reform is to emphasize not specific viewpoints but a specific procedure, namely, rational public discussion:

\section{Excerpt 7:}

In fact, up till now, debates between different standpoints in the society can help the public understand the issue of political reform from different angles. In this sense, all voices are constructive. (February 1, Ming Pao)

[Table 3 about here]

As Table 3 shows, the lexicons central to the idea of rational discussion - rationality (leih-sing), dialogue (deui-waah), communication (kautoung), and consensus (gouhn-sik)- 
all appeared more frequently in Ming Pao's editorials. Certainly, merely repeating the terminologies of rational deliberation would not automatically make the idea appealing. What needs to be done is to construct the possibility of 'rational debate'. This, first of all, involved constructing the different parties and entities in the debate as agents capable of rational discussion. In the above analysis, we have already seen how Ming Pao's editorials portrayed the Chinese government as a reasonable and well-intentioned agent through the uses of implicit and explicit acknowledgements. In addition, Ming Pao also invoked an image of a rational Hong Kong public to support the possibility of rational debate:

\section{Excerpt 8:}

We can imagine: If the Central Government adopted a milder and more pragmatic attitude, and the political representatives of various sectors of the Hong Kong society can sit down to sincerely and rationally discuss the political arrangement in year 2007 and beyond, what would be the reaction of Hong Kong people? Very naturally, Hong Kong people would think that the Central Government is open-minded and everything can be resolved through negotiation. (Ming Pao, March 5)

By using the positive adjective of 'open-minded' (hoi-mihng), a whole set of positive cultural presuppositions are indexed and invoked. In traditional Chinese texts about good politics in Chinese history, the word 'hoi-mihng' (can also be translated as 'enlightened') is used to describe central governments or kings who are willing to carry out reforms and to listen to the wishes of the people. The sentence 'everything can be resolved by negotiation' also indexes a time-honoured social practice in Chinese culture to resolve conflicts of views or interest through peaceful, polite ways of negotiating rather than open conflicts or fights. By using these words the editorial writer appeals to the shared traditional cultural practices of Chinese people and implicitly condemns any effort on any party to break harmony by initiating fights of words. 
Second, the possibility of rational discussion also comes from the existence of common values and pre-existing agreements, which serves as the common ground and starting point for discussion:

Excerpt 9:

Nevertheless, the Central Government and the SAR have an important common interest, that is, to maintain political stability in Hong Kong, and to practically resolve the problems faced in political reform. (February 8, Ming Pao)

Excerpt 10:

[Xinhua News Agency's statement] stressed that 'one country' is the premise of 'two systems'; the selection methods for Chief Executive and the legislature have to be consistent with the Basic Law; they also need to be in accordance with the actual situation [of Hong Kong] and the principle of gradual progress. All these have long been accepted by Hong Kong people. (February 12, Ming Pao)

Furthermore, the potential fruitfulness of rational discussion is suggested by the identification of a possible 'ending point' of the debate. In Ming Pao's editorials, this is done by the construction of a 'centrist position' in the overall storyline. For more concrete examples, in early June, ex-Chief Secretary of the Hong Kong government Anson Chan published an essay criticizing the Chinese Government, while 300 academics and professionals signed and published an announcement on a local newspaper expressing their worries about the future of Hong Kong. Ming Pao's editorial on June 10 described the two instances as the 'rise of centrist power.' In other editorials, Ming Pao also identified a group of 'centrist voters' among common citizens:

\section{Excerpt 11:}

Not a small number of centrist voters are now facing a dilemma. On the one hand they disagree with the way the Chinese government handled political reform in Hong Kong, 
thus they want to vote for the democrats so as to continue to fight for reasonable progress in democratization. On the other hand, they worry about the possibility that the government would be paralyzed and the [government] budget deficit would worsen if the democrats control the legislature. (May 7, Ming Pao)

In this passage, the centrist position is privileged. Centrist voters are not described as people who lack political commitments or who fail to make up their minds. Instead, the problems are regarded as residing in the Chinese government and the democrats. Both are not free from blame. The construction of this centrist position, implicitly treated as the mainstream public opinion, once again dissociates the democrats from their popular support and construct them as a political faction of radicals whose overly radical, irrational actions will harm the interest of the larger society. However, at the same time, the existence of this centrist position also implies that there is a middle ground that both the Chinese government and the democrats can both move towards.

In sum, through various means, Ming Pao has emphasized the possibility and desirability of rational discussions and implicitly appealed to the traditional Chinese cultural practice of resolving conflicts through polite negotiations. It thus freed itself from supporting either the democrats or the Chinese government. Nevertheless, emphasizing rational debate and polite ways of negotiating common ground and achieving consensus or compromise did not render criticisms completely unnecessary. Adhering to a procedure entails support for the values underlying the procedure. When particular actors and parties in the debate fail to follow the procedures, there would be the need to criticize them:

\section{Excerpt 12:}

Hong Kong people believe that differences can be narrowed down through rational discussions, and consensus can be reached in a step-by-step manner. The problem is that, when handling the issues of political reform in 2007 and 2008, the Central 
[Government] did not engage in a dialogue with Hong Kong people. It also did not provide the space for Hong Kong people to reach a consensus or compromise among themselves. It results in a divided and unstable society. (May 27, Ming Pao)

Ming Pao thus did occasionally criticize the Chinese government. However, by adding qualifications and by shifting the focus from the 'substance' (i.e., democracy) to the procedure (i.e., dialogue), political criticisms became less sensitive, yet also less powerful.

\section{The bias of objectivity}

By employing the rhetoric of objectivity and rational discussion, Ming Pao posited itself as an impartial arbitrator of an ongoing debate. But as numerous journalism scholars have recognized, reportorial and discursive practices of objective journalism can lead to their own biases (e.g., Tuchman, 1978; Fishman, 1980; Hackett and Zhao, 1998; Condit and Selzer, 1985; Erjavec, 2003). Ming Pao's rhetoric of objectivity is not an exception.

As pointed out earlier, in promoting rational debate, Ming Pao has emphasized that there are interests, values, and viewpoints already shared by China and Hong Kong. However, given the conservatism of the Chinese government, searching for common values between Hong Kong and China in effect means searching for the conservative values held by the Hong Kong public. This led to the prominence of the ideas of 'wan-dihng' (stability) and 'faahnwihng' (prosperity) in Ming Pao's editorials, as shown in Table 4.

[Table 4 about here]

There is no question that most Hong Kong people would want prosperity and stability. However, when these two single values are emphasized, the pursuit of democracy becomes instrumental. Democracy is needed because it promotes political stability, which in turn contributes to the pursuit of prosperity. This instrumentalist argument is not necessarily wrong, and at least it is an argument supportive towards democratization. The problem is whether it 
would displace other, non-instrumentalist arguments. An important non-instrumentalist argument is the notion of 'kyuhn-leih' (rights). Democracy can be regarded as important because it is Hong Kong people's natural or legal rights to have it. But as Table 4 shows, Ming Pao invoked the notion of people's rights to democracy only twice in the corpus. Apple Daily, in comparison, has adopted the rights perspective to a much larger extent.

Hence, Ming Pao's editorials were actually biased towards certain social values over others. The same applies to a number of key political principles regarding the relationship between China and Hong Kong. Since the early 1980s, the Chinese government has emphasized that Hong Kong will be governed under the principles of 'yat gwok, leuhng jai' (one country, two systems), 'gong yahn jih gong' (Hong Kong people ruling Hong Kong) and 'gou-douh jih-jih' (high degree of autonomy). In the past two decades, these principles were premises in political discourse regarding Hong Kong's relationship with China. In the debate on democratic reform, however, the Chinese government insisted that the issue is not merely a local matter. In other words, from China's perspective, 'high degree of autonomy' is irrelevant in this case.

This background allows us to understand the figures shown in Table 4. Placing more emphasis on common values and principles, Ming Pao mentioned 'one country, two systems' and 'Hong Kong people ruling Hong Kong' repeatedly. However, it used the phrase 'high degree of autonomy' less frequently than Apple Daily did. More important, the two papers invoked the principles for different purposes. While Ming Pao mentioned the principles mainly as commonly accepted principles and as bases of public discussions, Apple Daily, in contrast, was appropriating the principles to criticize China (as further discussed later).

Besides biases towards certain values and principles, Ming Pao's editorials also exhibited a bias towards established 'facts.' For Ming Pao, rational discussion must be grounded in facts and a proper understanding of the reality constraints. The purpose of public 
debate is to discover the best course of future action. In the terminology of stasis theory in the study of rhetoric, Ming Pao has adopted mostly the genre of deliberative rhetoric. This is contrary to Apple Daily's largely epideictic rhetoric, which focuses on meting out praises, blames or censures for contemporary actions and issues (Fahnestock, 1986).

The problem for the debate on democracy in Hong Kong is that not all parties have equal power in defining 'reality' and establishing 'facts.' As Ming Pao's deliberative rhetoric restricted the paper from challenging existing facts, its editorials thus exhibited a tendency to accept the 'reality' established one-sidedly by the Chinese government.

The best example is Ming Pao's treatment of the interpretation of the Basic Law by the National People's Congress. On March 27 and 31, Ming Pao argued against the course of action yet to be taken by the NPC, suggesting that it would damage the credibility of the Hong Kong government and the confidence of Hong Kong people. But after the NPC interpreted the Basic Law on April 6, Ming Pao stated on April 8:

\section{Excerpt 13:}

Although we did not wish to see this sudden interpretation of the Basic Law, the NPC did hold the legal right to do so....... Now, the pragmatic thing to do is to accept the political arrangement after the interpretation. This is the political reality. At the same time, [we] should focus on resolving concrete issues in Hong Kong's political reform. Similarly, the Central Government also needs to face the reality, facilitating political reform in Hong Kong, and responding to Hong Kong people's demand for democracy. (italics added)

In this extract, Ming Pao asserts and accepts China's legal right to interpret the Basic Law and asks the reader to be 'pragmatic'-to accept this political arrangement. The sentence 'This is the political reality' implicitly invites the reader to accept this arrangement (i.e., interpretation of the Basic Law by China) without any complaints so as to be 'pragmatic' 
and to focus 'concrete' issues in Hong Kong's political reform. However, what kind of concrete reforms can be achieved if it is defined one-sidedly by the Chinese government? Rhetorically the editorial writer writes, 'Similarly, the Central Government also needs to face the reality, facilitating political reform in Hong Kong, and responding to Hong Kong people's demand for democracy.' The appeal to the Chinese government to respond to Hong Kong people's demand of democracy comes after appealing to Hong Kong people to be pragmatic and to accept the political reality (that China has the final say in interpreting the law). This order is significant: the first appeal almost voids the force of the second appeal. The second appeal is done to complete the rhetorical balancing act of issuing requests to both parties in a dispute. Although it phrased Hong Kong people's demand for democracy as a 'reality' that China needed to respond to, inequality in actual political power means that the Chinese government can easily disregard such a 'reality.' As a consequence, an emphasis on facing the reality in this condition of inequalities in actual political power has contributed to a bias towards the actors who have the power to define what the reality is. In the end, Ming Pao's rhetoric of objectivity has tilted the editorials strongly towards the conservative side and have also contributed to the 'pragmatic' discourse circulating in the society that asks Hong Kong people to accept China's definition of what counts as political reform and what counts as democracy (to accept China's interpretation of the Basic Law as final). It legitimates this act of asking people to give up their rights by calling such acts 'pragmatic' (while others such as democrats might describe such acts as subservient).

\section{Discursive strategies for modifying political criticisms}

The above two sections have mainly focused on Ming Pao's discursive strategies for justifying and sustaining the overall storyline that it proffered in order to reduce the political sensitivity of its editorials. Apple Daily, as shown earlier, has adopted an overall storyline 
which is much more critical towards China. However, it does not mean that Apple Daily has had no concern at all with the political pressure they face. The paper has also adopted discursive strategies that render their political criticisms somewhat less sensitive than they would have been. In this sense, although Apple Daily's overall storyline and approach was critical, their critical stance was also modified by specific methods.

As mentioned, one method Apple Daily used to construct criticisms is to appropriate the discourses of the Chinese government. China's past promises were emphasized not as common values of Hong Kong and China, but as standards for judging the Chinese government's current actions:

\section{Excerpt 14:}

The so-called interpreting the Law is in fact changing the law. [The Law] can be revised today; [it] can be revised tomorrow. Attractive slogans such as 'High degree of autonomy,' 'Hong Kong people ruling Hong Kong,' and 'no change in fifty years' can all be regarded as history. (April 7, Apple Daily)

Excerpt 15:

According to the spirit of the Sino-British Joint Declaration and the Basic Law, political development of the Special Administrative Region is obviously Hong Kong people's internal affairs. Otherwise, what could it mean by 'Hong Kong people ruling Hong Kong' and 'high degree of autonomy'? (January 28, Apple Daily)

Apple Daily did not impose a set of 'foreign' criteria in evaluating China. It worked within the dominant universe of discourse provided by the Chinese government and articulated how the Chinese government has failed to keep its own promises. Doing so may involve changing the meanings of certain key terminologies in the dominant discourse. For example, for the Chinese government, 'Hong Kong people ruling Hong Kong' is not a democratic principle, as 'Hong Kong people' only means 'people from Hong Kong.' But for 
the democrats in the city and for Apple Daily, 'Hong Kong people' means 'the people of Hong Kong,' thus giving the principle a democratic meaning.

The same strategy of working within the dominant discourse can also be discerned in Apple Daily's emphasis on the 'rights' of Hong Kong people in developing democracy. Rather than grounding its argument on any theory of the 'natural rights,' the right for democracy is largely a legal right established in the Basic Law:

\section{Excerpt 16:}

Many Hong Kong citizens take to the street repeatedly not because they want to struggle against whom or make life difficult for the Central Government. They are only exercising the democratic rights that the Basic Law gives them; [they want] to establish a fully democratic system in Hong Kong. (January 2, Apple Daily)

More broadly, Apple Daily has used the strategy of articulating internal contradictions repeatedly in their editorials. For example, after a pro-China politician accused a Hong Kong political group of trying to overthrow the Communist regime in China, the editorial on February 9 criticized the politician for adopting an obsolete 'enemy vs. us' mindset, which, according to the same editorial, has already been abandoned by the Chinese government itself. Moreover, internal contradictions can also be articulated between the rhetoric and actions of different representatives of the Chinese government:

\section{Excerpt 17:}

'Seeking commonness within one country, retaining differences between two systems; all people have to be united, no matter which parties or classes they belong to.' The speech of Chinese Communist Party's United Front Department Director Ms. Liu Yandong is undoubtedly pleasing. Unfortunately, few Beijing officials speak in this way. Even fewer officials have adopted concrete measures to implement [what 
Liu said]. On the contrary, arbitrary attacks of people and groups holding alternative political views are commonplace. (May 27, Apple Daily)

What is implied in the passage is a diversity of voices and actors representing the Chinese government. In fact, a discursive strategy used by Apple Daily mainly between January and March, 2004, is decentralization of the Central government. In the period, Apple Daily criticized various mid- to low-level Chinese officials, leftists and conservatives in Hong Kong. But these individuals were treated as 'mediators' in the communication between Hong Kong and China, rather than as representatives of a unified Chinese government:

\section{Excerpt 18:}

[Damaging Hong Kong are] people who arbitrarily labeled others as 'defectors,' and those officials who only followed what others said. They are not only narrowing down the space for public criticism in Hong Kong and producing conflicts within the society; they are also not willing to reflect Hong Kong people's demand for democracy truthfully to the Central Government. As a result, the gap between the Central Government and Hong Kong people has become wider and wider. (March 6, Apple Daily)

In the storyline projected in the above excerpt, Chinese officials were cast as messengers who should transmit Hong Kong people's demand to the Central Government, and they were criticized for doing a poor job. The Chinese government was posited as an abstract entity which stayed beyond the fray and was therefore free from any blame. The Chinese government was given the 'benefit of the doubt.' The incompetence of the mediators was treated as the real problem. The overall storyline proffered by the Apple Daily was therefore modified through the construction of 'mediators.' The cast of actors representing the Chinese government was pluralized to include different voices, some better than others and some more progressive than others. Hence the authorial voice positions him/herself as not 
indiscriminately against 'the Chinese government' but just some incompetent or conservative actors who are not truly representative of the Chinese government. In effect, decentralization of the Chinese government is a means to avoid directly confronting the power center.

This is in line with how Apple Daily criticized the Hong Kong government throughout the debate on democratic reform. Although the role of the Hong Kong government was diminished by the Chinese government's active intervention, Apple Daily continued to criticize the former as failing to inform the Chinese government about the situation of and public opinion in Hong Kong:

\section{Excerpt 19:}

If [Chief Executive] C. H. Tung wants to have a good reputation in history, he should regard himself as sitting in the same boat with Hong Kong people. [He should] argue forcefully in front of national leaders Hu Jintao, Wen Jiabao, and Cheng Qinghong, so that the Central Government would understand that letting Hong Kong have democracy would not give rise to any negative effects. On the contrary, slowing down democratic development would involve a very high cost..... This is not what the Central Government would want to see. (Apple Daily, January 10)

In the above excerpt, the editorial writer appeals to Chief Executive C. H. Tung to consider himself as 'sitting in the same boat with Hong Kong people' if he wants to 'have a good reputation in history'. Here another well-established cultural practice is invoked: in traditional Chinese societies, the powerless people can only appeal to the powerful's concern for their reputation in history when they need to ask those in power to do something good. In this editorial, the writer did not draw upon other modern cogent grounds (e.g., human rights, democratic rights of citizens) for lodging a request to the most powerful person in Hong Kong (the Chief Executive). The request is linked to the traditional Chinese moral order regarding political relations (i.e., sets of rights and obligations) between the ruler and the ruled. The 
ideology of traditional political relations is thus sometimes reproduced rather than challenged, even in Apple Daily's editorial discourses.

However, decentralization can be employed only when the representatives' speeches and actions are non-binding. When an official merely says something, the statement can be treated as the official's personal view. In fact, for the government, having mid-level officials as 'mediators' could smooth out the policy-making process, as the government can test public reactions before committing to a course of action. But when binding decisions have to be made, the government could no longer stay beyond the fray. Therefore, in mid-March, when the issue of interpretation of the Basic Law by the NPC emerged, the strategy of decentralization began to fade away in Apple Daily's editorial. When a top-level organ in the Chinese government took action, the 'Central Government' could no longer be treated as an abstract entity. Apple Daily thus began to criticize the 'Central Government' directly.

Nevertheless, later on, as issues involving the making of binding decisions were no longer at the top of the agenda, Apple Daily resorted to decentralization again. For example, the editorials on June 21 and July 3 both criticized the Central Liaison Office, an organ of the Chinese government located in Hong Kong, for failing to act as the bridge between Hong Kong and China.

\section{Discussion}

In sum, the issue of democratic reform in Hong Kong has posed a serious dilemma for the Hong Kong media. To remain in line with local interests and public opinion, the Hong Kong media would have to voice their support for democratization. Given the way China denied further democracy to the Hong Kong public, media organizations that remain true to their watchdog role would also need to voice their criticisms towards China. Failure to do so is likely to damage their credibility in the public's eyes. 
However, the Hong Kong media have also been under the pressure not to provoke the Chinese government (Lam, 2003; Cheung, 2003). In fact, there are lines that both Apple Daily and Ming Pao did not cross in their editorials. For example, both newspapers did not criticize the Chinese national leaders personally. The names of China's President Hu Jintao and Premier Wen Jiabao were largely absent in the editorials.

But more interesting is how the things that can be said were said. As shown in the analysis, Ming Pao and Apple Daily have constructed different overall storylines and employed different discursive strategies in their editorials. Ming Pao attempted to maintain their credibility through emphasizing the norm of objectivity and the ideal of rational debate. It posited itself as the impartial arbitrator on the issue of political reform. The storyline it constructed cast government officials and politicians as belonging to different faction, with the Hong Kong public located at the center. Readers are thus implicitly invited to identify with a centrist position. These strategies reduced the need for the paper to directly criticize China, and they also reduced the sensitivity of the criticisms provided. Apple Daily, on the other hand, posited itself as the defender of public opinion and local interests. It constructed the storyline of a sovereign people having its rights and freedom encroached upon by a powerful entity. Hence the paper was much more direct in criticizing Chinese officials and conservative politicians, though it also modified the overall storyline and smoothed out the radicalism of its critiques by employing the discursive strategies of staying within the dominant discursive formation, articulating internal contradictions, and decentralizing the Chinese government.

The strategies employed by the two papers are different in two important ways. First, the strategies Apple Daily used might have reduced the paper's radicalism a bit, but overall speaking, the editorials remained highly critical towards the power holders. In fact, Apple Daily has been identified by some Chinese officials as a 'problem newspaper' in Hong Kong. 
Reporters of the paper are often denied access to China, and the organization itself is denied the opportunity to enter China's lucrative media market (Lam, 2003). On the contrary, Ming Pao's rhetoric of objectivity and rational discussion has led to a bias towards conservative values and the group(s) with the power to define 'reality.' This confirms the general argument in journalism studies that the norm of objectivity often inadvertently leads to biases towards the status quo (Tuchman, 1978; Fishman, 1980; Hackett and Zhao, 1998; Ettema and Glasser, 1998). It also shows that an emphasis on rational discussion would not be meaningful when the social and political conditions required for rational debate - such as the absence of huge inequalities in political power - simply do not exist. ${ }^{11}$

Second, Apple Daily did not refrain from directly and fiercely criticizing the Chinese government when the original strategy of decentralizing the Chinese government was no longer applicable. On the contrary, Ming Pao did not abandon their deliberative rhetoric even after it became clear that the Chinese government would not deliberate with the Hong Kong public.

The strategies of Ming Pao, therefore, are much more questionable in the present case. It seems that they were only used to mask the paper's docility as 'professionalism.' In this sense, Ming Pao can be criticized as having practiced a form of self-censorship in their editorials on the debate on democratic reform in Hong Kong.

This is not to say that Ming Pao's editorial writers have consciously self-censored what they wrote. It is possible that Ming Pao's editorial team sincerely believes in objective journalism. After all, objectivity is a dominant journalistic norm in many countries as well as in Hong Kong (Chan et al., 1996). Moreover, as discussed earlier, the politics of selfcensorship in Hong Kong is complicated. The commercial nature of the media means that news organizations have to take care of both political and market pressure. A range of 'strategic rituals,' hence, was devised by media organizations to help minimize both political 
risks and loss of credibility (Lee, 2000). Presumably, if such strategies are used skillfully, they would allow the media to handle political pressures without hugely compromising their own integrity. Intensified objectivity has been one such strategy (Lee et al., 2004).

However, in the present case, the strategy of objectivity has constrained Ming Pao's ability to play its watchdog role properly. After all, this study focuses on editorials, the site for media organizations to actively participate in public debate (Le, 2003). Editorials are where objectivity does not need to be strictly applied. In fact, as journalism scholars have recognized, the spatial separation between news articles and opinion-editorial pieces is a means for a newspaper to signify its commitment to objective news reporting on the one hand, while retaining a space for the paper to express its own viewpoint on the other (Tuchman, 1978; Hackett and Zhao, 1998). Emphasizing the norm of objectivity in editorials only highlights a news organization's reluctance to state its own views.

Generally speaking, this study shows the importance of language in the politics of press freedom. The lack of press freedom and the existence of censorship or self-censorship have usually been discussed in terms of the existence of taboo areas and topics that the media cannot cover. However, there may not always be a clear boundary separating the allowed and the not allowed. In the gray, in-between area, the key to the politics of press freedom would be how to make certain things reportable through discursive means. At the same time, the politics of self-censorship may also involve media organizations discursively justifying their reluctance to say certain things. It might involve explicit, public justifications (Graber, 2004), but it could also involve implicit justifications through the use of discursive strategies in news coverage and editorials, such that self-censorship puts on a mask and is presented as something else. The present study has pointed to the usefulness of positioning theory and the analysis of storylines and subject positions (Davies and Harre, 1990; Harre and Langenhove, 1999) to studying the topic. It has also identified a number of strategies relevant to the politics 
of press freedom and self-censorship in Hong Kong. Future studies can focus on other cases, in Hong Kong and in other countries, and identify more strategies used for the purpose. Theory-based typologies of the discursive strategies can also be developed.

In addition, a more comprehensive analysis of the discursive politics of selfcensorship can also include considerations of how the public reads the media texts. In the present study, it is argued that the strategies used by the newspapers are for the purpose of maintaining credibility and handling political pressure. But admittedly, the present study cannot tell if such strategies indeed help the newspapers to maintain credibility in the eyes of the public. This latter question has to be considered in terms of how readers understand and decipher the texts. In fact, studies of political communication in authoritarian societies have sometimes emphasized the audience's ability to read between the lines (Mickiewicz, 2000). The 'active audience' should be taken into account in the study of media self-censorship.

Finally, it should be noted that such a discursive politics of press freedom and selfcensorship is likely to be particularly important in a transitional society such as Hong Kong. More precisely, Hong Kong is a city where an authoritarian political system, a public and journalistic commitment to press freedom, and a commercial media system co-exist. The absence of formal censorship means that few things are, strictly speaking, unspeakable. Yet the political situation also constrains the range of ideas that can be expressed completely freely. In other words, the gray area between the allowed and the not allowed is particularly large. The existence of this large gray area provides the condition for language to play a significant role in the politics of self-censorship. 


\section{Tables}

Table 1 The lexicons of criticism

\begin{tabular}{|lcc|} 
& Apple Daily & Ming Pao \\
& $(\mathrm{N}=68)$ & $(\mathrm{N}=51)$ \\
Interfere/Intervene (gaai-yahp/gon-yuh) & 5 & 1 \\
Violent/Unreasonable (chou-bouh/mouh-leih) & 21 & 0 \\
Disregard (moh-sih) & 5 & 0 \\
Hat (mou-ji) & 9 & 3 \\
Sell the country/Han defector (maaih-gwok/hon-gaan) & 20 & 0 \\
\hline
\end{tabular}

Note: The figures are frequencies of occurrences. They include only those instances in which the words/phrases were used in association with the actions or policies of the Chinese government throughout the debate on democratic reform in Hong Kong.

Table 2 Mentioning and characterization of agents in the debate

\begin{tabular}{|lcc|}
\hline & Apple Daily & Ming Pao \\
& $(\mathrm{N}=68)$ & $(\mathrm{N}=51)$ \\
Central government & 232 & 151 \\
Beijing & 136 & 92 \\
Power holder (dong-kyuhn-je) & 18 & 1 \\
The Democratic Party & 7 & 39 \\
The Democratic Faction (mahn-jyu-paai) & 1 & 220 \\
\hline
\end{tabular}


Table 3 The lexicons of rational deliberation

\begin{tabular}{|lcc|}
\hline & Apple Daily & Ming Pao \\
& $(\mathrm{N}=68)$ & $(\mathrm{N}=51)$ \\
Rationality (leih-sing) & 15 & 52 \\
Rational discussion & 0 & 12 \\
Communication (kau-toung) & 29 & 68 \\
Dialogue (deui-waah) & 2 & 54 \\
Consensus (gouhn-sik) & 15 & 25 \\
\hline
\end{tabular}

Table $4 \quad$ Social values and political principles

\begin{tabular}{|lcc|}
\hline & Apple Daily & Ming Pao \\
& $(\mathrm{N}=68)$ & $(\mathrm{N}=51)$ \\
Stability (wan-dihng) & 20 & 47 \\
Prosperity (faahn-wihng) & 6 & 23 \\
Rights (kyuhn-leih)* & 21 & 2 \\
One country, two systems (yat gwok leuhng jai) & 51 & 36 \\
High degree of autonomy(gou-douh jih-jih) & 33 & 28 \\
HK people ruling HK (gong yahn jih gong) & 15 & 0 \\
\hline
\end{tabular}

*For the term 'rights,' the figures also include instances in which the term is used for various democratic rights, such as rights to liberty and rights to free speech, of Hong Kong people. 


\section{References}

Amin, H. (2002) 'Freedom as a Value in Arab Media: Perceptions and Attitudes among Journalists', Political Communication 19(2): 125-135.

Bagdikian, B. (2004) The New Media Monopoly. Boston: Beacon.

Bohman, J., and Rehg, W. (Eds.). (1997) Deliberative Democracy: Essays on Reason and Politics. Cambridge, Mass.: MIT Press.

Chan, J. M., and Lee, C. C. (1991) Mass Media and Political Transition. New York: The Guilford Press.

Chan, J. M., and Lee, F. L. F. (2005). The formation of public protest? A study of three largescale demonstrations. Occasional Paper, the Institute for Asia-Pacific Studies, Chinese University of Hong Kong.

Chan, J. M., Lee, P. S. N., and Lee, C. C. (1996) Hong Kong Journalists in Transition. Hong Kong: Hong Kong Institute of Asia Pacific Studies, Chinese University of Hong Kong.

Chan, J. M., and So, C. Y. K. (2004) 'The Surrogate Democracy Function of the Media: Hong Kong Citizens' and Journalists' Evaluations of Media Performance', in S.K. Lau et al (Eds.), Indicators of Social Development (pp. 1249-276). Hong Kong: Hong Kong Institute of Asia-Pacific Studies.

Cheung, A. S. Y. (2003) 'Hong Kong Press Coverage of China-Taiwan Cross-straits Tension', in R. Ash, P. Ferdinand, B. Hook, R. Porter, and F. Ash (Eds.), Hong Kong in Transition (pp. 210-225). London: Routledge.

Condit, C. M., and Selzer J. A. (1985) 'The Rhetoric of Objectivity in the Newspaper Coverage of a Murder Trial', Critical Studies in Mass Communication 2(3): 197-216.

Davies, B. and Harre, R. (1990) Positioning: The Discursive Production of Selves. Retrieved on 3 August 2005, from: www.massey.ac.nz/ alock/position/position.htm. 
Ettema, J., and Glasser, T. L. (1998) Custodians of Conscience. New York: Columbia University Press.

Erjavec, K. (2003) 'Media Construction of Identity Through Moral Panics: Discourses of Immigration in Slovenia', Journal of Ethnic and Migration Studies 29(1): 83-101.

Fahnestock, J. (1986) 'Accommodating Science: The Rhetorical Life of Scientific Facts', Written Communication 3(3): 275-296.

Fishkin, J. S., and Laslett, P. (Eds.). (2003) Debating Deliberative Democracy. Oxford: Blackwell.

Fishman, M. (1980) Manufacturing the News. Austin: University of Texas Press.

Geertz, C. (2000). The Interpretation of Culture. New York: Basic Books.

Graber, D. A. (2004) 'Styles of Image Management During Crises: Justifying Press Censorship', Discourse \& Society 14(5): 539-557.

Hackett, R. A., and Zhao, Y. (1994) 'Challenging a Master Narrative: Peace Protest and Opinion Editorial Discourse in the United States Press During the Gulf War', Discourse \& Society 5(4): 509-541.

Hackett, R. A., and Zhao, Y. (1998). Sustaining Democracy? Journalism and the Politics of Objectivity. Toronto: Garamond Press.

Harre, R. and Langenhove, L. V. (eds.) (1999) Positioning Theory. Oxford: Blackwell Publisher.

Holbig, H. (2003) 'Hong Kong Press Freedom in Transition', in R. Ash, P. Ferdinand, B. Hook, R. Porter and F. Ash (Eds.), Hong Kong in Transition (pp. 196-209). London: Routledge.

Lau, T. Y., and To, Y. M. (2002) 'Walking a Tight Rope: Hong Kong's Media Facing Political and Economic Challenges since Sovereignty Transfer', in M. K. Chan and A. So (Eds.), Crisis and Transformation in China's Hong Kong. New York: M. E. Sharpe. 
Le, E. (2003) 'Active Participation within Written Argumentation: Metadiscourse and Editorialist's authority', Journal of Pragmatics 36(4): 687-714.

Le, E. (2004) 'Information Sources as a Persuasive Strategy in Editorials: Le Monde and the New York Times', Written Communication 20(4): 478-510.

Lee, C. C. (1998) 'Press Self-censorship and Political Transition in Hong Kong', Harvard International Journal of Press/Politics 3(2): 55-73.

Lee, C. C. (2000) 'The Paradox of Political Economy: Media Structure, Press Freedom, and Regime Change in Hong Kong', in C. C. Lee (Ed.), Power, Money, and Media. Illinois: Northwestern University Press.

Lee, F. L. F., Chan, J. M., and, So, C. Y. K. (2004) 'Politics of Objective Journalism in China's Hong Kong', paper presented at the International Communication Association Annual Convention, New Orleans, USA, May 2004.

Lee, F. L. F., Chan, J. M., and, So, C. Y. K. (2005) 'Evaluation of Media and Understanding of Politics: The Role of Education among Hong Kong Citizens', Asian Journal of Communication 15(1): 37-56.

Lee, P. S. N., and Chu, L. (1998). 'Inherent Dependence on Power: the Hong Kong Press in Political Transition', Media, Culture \& Society 20: 59-77.

Li, Y. H. (2004) 'Representing the Underprivileged? A Case Study of the News Media under Marketization and the Peasant Immigrant Labor Issue in China', paper presented at the 2004 Annual Conference of the International Communication Association.

McChesney, R. (2004) The Problem of the Media. New York: Monthly Review Press.

Mickiewicz, E. (2000) 'Institutional Incapacity, the Attentive Public, and Media Pluralism in Russia', in R. Gunther and A. Mughan (Eds.), Democracy and the Media (pp. 85-121). New York: Cambridge University Press.

Rawls, J. (1973) A Theory of Justice. New York: Oxford University Press. 
Ryle, G. (1965). The Concept of Mind. New York: Barnes and Noble.

Sacks, H. (1966/1992). Lecture 18-'Hotrodders' as a revolutionary category. In Gail Jefferson (Ed.), Lectures on Conversation (pp. 396-403). Oxford: Blackwell.

Schell, O. (1996) ‘Self-censorship in Hong Kong’, Media Studies Journal 10(4): 53-54.

Sciutto, J. E. (1996) 'China's Muffling of the Hong Kong Media', in M. J. Skidmore (Ed.), Hong Kong \& China Pursuring a New Destiny (pp. 131-143). Singapore: Toppan.

Silverstein, M. (2003). Talking Politics: The Substance of Style From Abe to ' $W$ '. Chicago: Prickly Paradigm Press.

Sukosd, M. (2000) 'Democratic Transformation and the Mass Media in Hungary: From Stalinism to Democratic Consolidation', in R. Gunther and A. Mughan (Eds.), Democracy and the Media (pp. 122-164). New York: Cambridge University Press.

Tuchman, G. (1978) Making News. New York: Free Press.

van Dijk, T. A. (1988). News as Discourse. Hillsdale: Lawrence Erlbaum Associates.

Zhao, Y. (1998) Media, Market, and Democracy in China. Urbana: University of Illinois Press. 


\section{Endnote}

1 However, this does not mean that the Chinese government has not tried to influence or direct Hong Kong affairs from behind the scene.

2 With the exception of Radio Television Hong Kong, which is a public broadcaster, all other media organizations in Hong Kong are commercial organizations.

3 Nowadays, there are 15 local dailies serving seven million residents in Hong Kong.

$4 \quad$ There are also media organizations in Hong Kong which have adopted a de-politicized approach to news. A few media have even become strongly pro-China in their political coverage. The present paper, however, concerns with the media organizations that attempt to stay in line with the 'mainstream' of Hong Kong society.

5 Some of the polls were conducted by the Public Opinion Programme at the University of Hong Kong. Relevant poll findings are available on the Internet: http://hkupop.hku.hk. 6 The debate in 2004 only addressed the Chief Executive election in 2007. It did not provide a plan for long-term political development in the city. Presumably, direct election of the Chief Executive in 2012 remains a possibility.

7 The onsite survey was conducted by Prof. Joseph Man Chan of the Chinese University of Hong Kong and Dr. Robert T. Y. Chung of Hong Kong University. For discussions of relevant findings from the survey, see Chan and Lee (2005).

8 In the first few days of July, 2004, a number of editorials were published by the two papers addressing the July 1 demonstration. Afterwards, the issues related to democratic reform have become less prominent in the news agenda.

9 Though the phrase 'thick description' is associated mainly with ethnography in anthropology, the term was used first by Ryle (1965) and was only later borrowed by Geertz (2000) to point to the constructivist and interpretive nature of ethnographic work. Hence, applying the phrase, at least in its general sense, to analysis of texts should not be a problem. 
10 In this paper all Chinese words are transcribed in the Yale system which has been designed for transcribing Cantonese sounds. We choose to transcribe the Cantonese pronunciations of the words as they represent the way these words are perceived by most people in Hong Kong who speak Cantonese as their first language and mostly read Chinese texts with Cantonese pronunciations.

11 The possibility for rational debate and the conditions necessary for it has been a key question debated by political theorists in the past 15 years. See Fishkin and Laslett (2003) and Bohman and Rehg (1997). 